\title{
U-PB AND LU-HF ISOTOPIC SYSTEMS IN ZIRCONS FROM SOME KIMBERLITES OF THE SIBERIAN PLATFORM AND FROM EBELIAKH ALLUVIAL DEPOSIT: AGE AND GEOCHEMIC PECULIARITIES OF THE SOURCE ROCKS.
}

\author{
Lokhov K.I.", Lukyanova L.I. ${ }^{* *}$, Lepekhina E.N..** Kapitonov I.N. ${ }^{* *}$, Shokalsky S.P. ${ }^{* *}$, Shevchenko S.S. ${ }^{* *}$, \\ Antonov A.V.**, Sergeev S.A.** \\ * St.-Petersburg State University, geological faculty, St.-Petersburg, Russia; \\ **VSEGEI, St.Perersburg, Russia.Kirill_Lokhov@vsegei.ru
}

The important practical task is determination of possible magmatic sources of diamonds in alluvial deposits. In alluvial deposits together with diamonds and specific deep origin minerals also are concentrating zircons, which carry unique genetic and age information by $\mathrm{U}-\mathrm{Pb}$ and $\mathrm{Lu}-\mathrm{Hf}$ isotopic systems. In the North-East of the Siberian platform it is known rich by diamonds Ebeliakh alluvial deposit, containing diamonds of different morphological types. The type of its base magmatic source is still under discussion. In this work we carried attempt of determination of the magmatic base source of the Ebeliakh alluvial deposit of diamonds, basing on comparison of zircons from this deposit with zircons from some kimberlite pipes of the Siberian platform. Among studied objects of the Jakutian diamond bearing province were investigated zircons from diamond -rich, -poor and -free kimberlites from different fields of Anabar-Olenek region and of different age. Among the studied kimberlites are present some pipes from the Chomirdakhskaya field (Druzba), Kuyokskoye field (Ruslovaya), Molodinskoye field (Khrizolitovaya), Kuranakhskoye field (Anomaliya 20/85, Malokuonapskaya 1 and 2), Verkhnemunskoye field (325 y of Jakutia and Zapoyarnaya). In different pipes from there are various distribution patterns of rounded and table-cut diamonds.
Kimberlitic zircons can be identified by morphology type, characteristic cathodoluminecsence images, low uranium concentrations, and by specific REE distribution patterns. Our experience have shown that the most robust parameters for determination of zircon genesis can be done mostly by isotopic geochemical investigations, based on $\mathrm{Hf}-\mathrm{Nd}$ isotopic systematics derived from $\mathrm{Sm}-\mathrm{Nd}$ whole rock and Lu-Hf zircon isotopic systems (Lokhov, e.a., 2009a).

Isotopic investigation was carried out in Center of Isotopic Research (CIR) VSEGEI by methods of local isotopic analysis: at first was studied U-Pb isotopic system by SIMS SHRIMP II with spatial resolution beam diameter $\mathrm{d}=15$ $\mathrm{mkm}$ and depth $\mathrm{h}=2 \mathrm{mkm}$, and then in the same locations by laser ablation LA-MCICPMS Finnigan Neptune/DUV-193 with $\mathrm{d}=40 \mathrm{mkm}$ and $\mathrm{h}=30-40 \mathrm{mkm}$, following (Lokhov, e.a., 2009b). For isotopic Hf-Nd systematization some data on $\mathrm{Sm}-\mathrm{Nd}$ isotopic system in kimberlites were taken from published materials (Agashev, e.a., 2000, Bogatikov, e.a., 2004, Kostrovitsky, e.a., 2007), some part of data were obtained in CIR VSEGEI.

Isotopic Hf-Nd systematization has shown, that among studied kimberlites Paleozoic and Mezozoic ones are corresponding to known type 1 (fig.1). Mid Triassic kimberlites 


\section{0 $^{\text {th }}$ International Kimberlite Conference, Bangalore - 2012}



Fig.1. isotopic Hf-Nd systematization of some kimberlites of the Siberian platform. Gray dotted lines are marking correlation for magmatic rocks "Hf-Nd terrestrial array", ellipses - fields corresponding to known kimberlites (Nowell, e.a., 2004) 1- first type, 2- second type, 3- transitional type.

(Malokuonapskaya and Anomaliya 20/85 pipes) are forming specific anomalous type, for them are characteristic some excesses of radiogenic hafnium relative to neodymium, in comparison with known type 1, 2 and transitional kimberlites. There can be different reasons of these excesses, and one is that is a result of higher degree of partial melting of garnet bearing mantle source under impact of thermal field of Early - Triassic plume, with which is connected trap magmatism on the South-West of the Siberian platform.

For zircons from Ebeliakh alluvial deposit was obtained $\mathrm{U}-\mathrm{Pb}$ age $232-242 \mathrm{Ma}$ (one grain $127 \mathrm{Ma})$ and $\varepsilon \mathrm{Hf}(\mathrm{T})=+6.6-+10.5$, and correspond to the high values which are characteristic for founded Mid - Triassic kimberlites of anomalous type (Malokuonapskaya and Anomaliya 20/85 pipes). Hence, the base magmatic source can be genetically connected with anomalous kimberlites of Mid- Triassic age.

As in data set from (Nowell, e.a., 2004), studied kimberlite zircons are characterizing by exceptionally low values of ${ }^{177} \mathrm{Lu} /{ }^{176} \mathrm{Hf}<0.0001$ (fig.2). The interesting fact is that in younger zircons this ratio is slightly increasing.

Low value of luthetium - hafnium ratio in kimberlite zircons $\left({ }^{177} \mathrm{Lu} /{ }^{176} \mathrm{Hf}<0.0001\right)$ is important additional geochemical parameter for

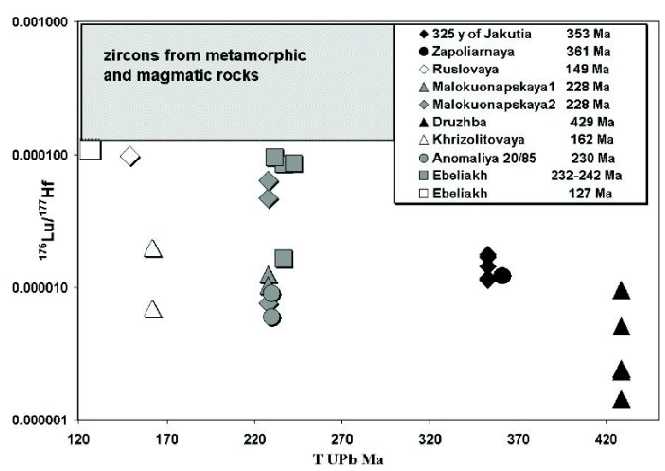

Fig.2. Values of $\mathrm{Lu} / \mathrm{Hf}$ ratio in zircons from kimberlites and from alluvial deposit Ebeliakh.

identification of zircons formed in deep kimberlite sources, which has significant importance for investigation of zircons from alluvial deposits.

Comparison of initial hafnium isotopic ratios (Fig.3) show that all of the kimberlite sources from the Siberian platform are slightly depleted: the characteristic points are between depleted mantle DM and uniform chondritic reservoir CHUR evolution lines. The same also is characteristic for the Ebeliakh zircons deep source. According to these data the deep source of the Ebeliakh diamonds is not different from typical kimberlitic ones.

In the Ebeliakh region numerous and rich by diamonds alluvial deposits, are present diamonds of different morphological types: typical kimberlitic table-cut crystals, imact crystals, and rounded crystals of the Brasilian type. For the last ones base magmatic sources are unknown. The obtained data can provide evidence, that base magmatic source of rounded crystals of diamond could be, founded at first, kimberlites of anomalous type such as Malokuonapskaya and Anomaliya 20/85 of Mid - Triassic age.

The data obtained can help for investigation of nature of the base magmatic sources for numerous analogous alluvial deposits of diamonds in some areas of Russia, Brasil, Indonesia Australia and other regions. 


\section{0 $^{\text {th }}$ International Kimberlite Conference, Bangalore - 2012}

\section{References:}

Agashev A.M., Orihashi Y, Vatanabe T. e.a. Isotopic geochemical characteristics of kimberlites of the Siberian platform in connection with problem of their origin. Geologiya I Geofizika 2000, v. 41. ${ }^{1}$ 1, p. 90-99 (in Russ).

Bogatikov Î. À., Kononova V. À. e.a. Petrochemical and isotopic variations of kimberlites of Jakutia and their reasons. Geokhimiya 2004, ${ }^{1}$ 9, p. 915 939 (in Russ).

Kostrovitsky S.I., Morikio T. Isotopic - geochemical systematization of kimberlites of the Siberian platform. Geologiya i Geofizika 2007, v. 48, ${ }^{1} 3$, p. 350-371 (in Russ).
Lokhov K.I., Saltykova T.E., Kapitonov I.N., e.a. Correct interpretation of $\mathrm{U}-\mathrm{Pb}$ age by zircons basing on isotopic geochemistry of hafnium and neodymium (on example of some magmatic complexes of basement of East-European platform). Regionalnaya geologiya I metallogeniya 38, 2009a, p.62-72 (in Russ).

Lokhov K.I., Kapitonov I.N., Prasolov E.M., e.a. Extremely radiogenic hafnium in zircons from Precambrian calsiphyres. Doklady Earth Sci. 2009b, v. 425A, ${ }^{1} 3$, ñ. $463-466$.

Nowell D.M, Pearson D.G., Bell D.R., e.a. Hf isotope systematics of Kimberlites and their Megacrysts: New constrains on their Source regions.// Journal of Petrology, 2004, aug 1, p. 1-30. 